\title{
Assessing project management maturity in the area of knowledge management in select companies
}

\author{
Seweryn Spalek \\ Faculty of Organisation and Management, Silesian University of Technology, Gliwice, Poland \\ Email address: \\ spalek@polsl.pl
}

To cite this article:

Seweryn Spalek. Assessing Project Management Maturity in the Area of Knowledge Management in Select Companies. International Journal of Economics, Finance and Management Sciences. Vol. 2, No. 2, 2014, pp. 164-170. doi: 10.11648/j.ijefm.20140202.18

\begin{abstract}
Project management is of high significance for companies nowadays. This is of special interest for those organizations which operate in the multi-project environment. For them, it is crucial to find out how good they are at managing projects. To that end, the project management maturity assessment concept was developed. However, getting a picture of the organization is only the first step. The second should be to analyze the results and, based on them, undertake appropriate activities in order to increase efficiency in project management. There are various models of project management maturity (PMM) assessment in different areas. In investigating current management trends, the knowledge management concept is one of the most important ones. Therefore, in author's opinion the modern PMM model should definitely address the knowledge management area. In the article based on the world-wide empirical study of 400 companies, I discuss the PMM level in the knowledge management area. The assessment was done using the author's PMM model which measured maturity in four areas: methods and tools, human resources, project environment and knowledge management. The investigated companies were from the machinery, construction and information technology branches. The major research effort was focused on the machinery industry as this sector of the economy is not well recognized in empirical research related to project management. Moreover, the main aim of the study was to compare Polish and foreign companies via an examination of diverse industries. The results of the study revealed that, in general, the foreign companies are at a higher PMM level in the knowledge management area than their Polish counterparts. This difference is discussed in the article. Among the industries, the most mature was information technology and this is also elaborated on. In addition, the study shows that the mean maturity level of all investigated companies is rather small. The reasons for that fact are explained and the implications for the companies are outlined.
\end{abstract}

Keywords: Project Management, Maturity, Knowledge, IT, Information Technology, Construction, Machinery Industry, Company, Empirical Study, Research, Assessment, Level

\section{Introduction}

The increase in maturity in project management relates to a company's activities and processes which are undertaken to enhance the continuous progress in the planning and execution of projects. The result of the assessment of project management maturity (PMM) shows how good the company is at managing projects. Furthermore, they can be used to indicate areas for potential improvement and support the decision makers where and when to invest limited funds [1].

Companies are managing an increasing number of projects nowadays. This situation has been observed for more than a decade and the companies who are able to not only challenge, but also profit out of that, gain a competitive advantage [2]. However, in order to benefit from the lessons learned, the organization needs to possess an efficient knowledge management system. It relates to the identification, capturing, developing, sharing and applying of knowledge [3] acquired in projects. This considers the ongoing project knowledge transfer and reuses the knowledge from past projects. The issue of project knowledge management [4] is of the utmost importance in the multi-project environment [5], as there are numerous sources of knowledge which can be applied to ongoing projects.

Therefore, the purpose of this paper is to investigate project management maturity in select companies in the knowledge management area. 


\section{Literature Review}

Management of project-related issues has its relevant place in the literature dedicated to Operations Management and Company Management [6,7]. There is common understanding on Project Management standards and methods, which are discussed by various authors $[8,9]$ and non-profit organizations [10-12].

Project management covers a wide range of company activities. It relates mostly to the tools and techniques that are widely used in the planning and execution processes. However, other domains have prevailed recently. One of them is dedicated to the people involved in projects. Their experience and knowledge is crucial for project success. The other is about both the external and internal environments that projects operate in. Another domain can be dedicated to Procurement Management. One can distinguish from a couple to several different domains that projects operate in. Regardless of the number of domains, there are also processes related to the different activities of the company $[13,14]$.

An investigation into the processes [15] related to managing projects helps us to understand how good the company is in project management or how mature it is in managing projects.

There are several models for assessing project management maturity (PMM). Wendler [16], in his work, investigated 237 scientific papers that focused on PMM and noticed that they proposed 108 distinct PMM models. Hillson [17] states that there are over fifty models which are used in practice, concluding that they are mostly single case-study oriented and, therefore, their application to wider populations is limited. Moreover, different authors discuss the applications of the PMM models in relation to industry specific issues [18-31]. However, the vast majority of them are built on the Capability Maturity Model Integrated (CMMI) [32].

Regardless of the maturity model, they mostly measure the maturity level on a scale of 1 to 5 , where 1 is the lowest and 5, the highest [33]. The assessment is performed in each designated maturity area (e.g. methods, project environment) separately. A different approach is used in the Organizational Project Management Maturity Model PMI OPM3 ${ }^{\circledR}[34]$, where maturity is perceived as continuous development and the processes in the company are compared to the list of best practices. Moreover, the list is constantly evolving through time.

It is remarkable that the most common project management maturity models do not address knowledge management as a separate entity for maturity assessment. I argue that, as knowledge management is of high importance in general management nowadays [35-37] and in project management practice [38-41], it should be distinguished as a distinct area of maturity assessment.

Moreover, the majority of empirical studies related to project management maturity are dedicated to the information technology and construction industries [42].
Therefore, there is a gap of knowledge and a need to investigate the other branches as well. One of the branches which is not recognized in project management studies is the machinery industry [43]. This sector of the economy produces machines and devices which are then utilized by other companies [44]. It plays a key role in local and global markets [45]. Therefore, it is important to conduct project management related studies in machinery industry companies. Thus, I decided to investigate their project management maturity level. Furthermore, to obtain a wider research context, the information technology and construction companies are studied as well.

\section{Research Method}

The empirical study on the project management maturity levels was performed using a web-based questionnaire. As a result of posting the survey on industrial forums, advertising it during trade fairs and targeted mailing lists, the data from 447 companies were collected, as shown in Table 1. Due to the relative inaccessibility of some companies, it was difficult to establish a solid survey return rate as the internet fora announcements can be read by numerous individuals and no data on the number of readers can be obtained. The only data which could theoretically be gathered is the number of times that an announcement was displayed. However, it not the same as reading it and, in some forums, there is no possibility of accessing such data.

To ensure the best data quality, all completed questionnaires were checked for integrity, accuracy, relevance and completeness of the data. All questionnaires not meeting that rigid criteria were rejected.

Table 1. Companies participating in the study by industry

\begin{tabular}{llll}
\hline Industry & Frequency & Percent & $\begin{array}{l}\text { Cumulative } \\
\text { Percent }\end{array}$ \\
\hline Machinery & 256 & 57.3 & 57.3 \\
Construction & 110 & 24.6 & 81.9 \\
Information Technology & 81 & 18.1 & 100.0 \\
Total & 447 & 100.0 & \\
\hline
\end{tabular}

As the maturity concept is mostly associated with larger organizations, in this study the data from those companies employing 50 or more people were analyzed. Such companies numbered 429. The major (approximately 50\%) group consisted of Polish companies. Of them, 126 were machinery, 40 information technology and 61 construction industry firms.

The foreign companies were widely dispersed among different countries and comprised of machinery (112), information technology (41) and construction (49) industry firms. They were mostly companies from the western part of Europe and from North America.

The assessment of the maturity level was performed using the author's own model which was developed 
specifically for the machinery industry study [46]. In the model, the measurement was conducted in four separate areas: methods and tools, human resources, project environment and knowledge management. The model was designed to fit into the quantitative studies. Due to the growth in universal mechanisms, its usage is not limited to the machinery industry only.

The possible results of the maturity assessment are on a scale of 1 to 5 , where 1 indicates the lowest and 5, the highest level of maturity. The meaning of the maturity levels is stated in Table 2.

Table 2. Maturity levels used in the assessment model

\begin{tabular}{cl}
\hline Level & Name \\
\hline 5 & Self-improvement \\
4 & System Management \\
3 & Appliance \\
2 & Standardized \\
1 & Initial \\
\hline
\end{tabular}

The initial level of maturity means that projects are, in fact, not organized in the company. The knowledge possessed by individuals involved in project-related processes is of a different nature and is not commonly recognized.

The second level, 'standardized', indicates that some of the projects are managed in a structured way. However, it is still not a cross-project standard to manage the knowledge identification, capture, development, sharing and deployment processes.

The third level, 'appliances', can be reported by the company when the majority of projects are included in the project knowledge management system.

In the fourth level of 'system management', all projects are part of the comprehensive approach to knowledge in projects. At this stage, the knowledge is transferred to and from the projects on a regular basis.

The fifth level of 'self-improvement' is the highest one and indicates the company's awareness of the role that knowledge management plays in project management. Therefore, the company runs those processes which should help to identify areas for improvement.

In the study, the measurement was conducted in four areas: methods and tools, human resources, project environment and knowledge management. The discussion in this article relates to the latter one only.

\section{Results and Discussion}

The reliability of the data was checked using Cronbach's Alpha tests, which rendered a value of over 0.8 in each group of companies.

\subsection{Comparison of Industries}

The descriptive data analysis shows that, irrespective of the country of origin of the company, the lowest maturity levels in the knowledge management area were noticed in the machinery industry (IND). Then, the maturity level increases slightly in construction (CONS) firms, to reach a peak for information technology (IT).

Further analysis revealed that the spread of data is relatively low across industries. However, it is the lowest for Polish information technology ones, and the highest for Polish machinery and foreign information technology firms, while the construction and foreign machinery industry companies are somewhere in between.

The minimum maturity value of 1 was reported by some Polish companies in each industry, while in foreign entities, it was only evident in the information technology sector. What's more, the minimum value of maturity reached by foreign construction and machinery businesses was level 2 . The highest level (5) was noticed in both the machinery and foreign IT industries. It is remarkable that the construction branch reported level 3 as the highest attained. It means that, regardless of the origin of the company, there were no reported cases of having reached levels 4 or 5 . The same situation was found in the Polish IT branch.

Detailed descriptive statistics are shown in Table 3.

Table 3. Descriptive statistics by company origin (POL - Poland, OTHERforeign company) and by industry (IND-Machinery, CONS- Construction, IT- Information Technology)

\begin{tabular}{lllll}
\hline & & IND & CONS & IT \\
\hline POL & Mean & 1.59 & 1.52 & 2.05 \\
& Median & 1 & 2 & 2 \\
& Std. Deviation & 0.78 & 0.54 & 0.39 \\
& Minimum & 1 & 1 & 1 \\
& Maximum & 5 & 3 & 3 \\
\hline \multirow{6}{*}{ OTHER } & Mean & 2.18 & 2.35 & 2.51 \\
& Median & 2 & 2 & 2 \\
& Std. Deviation & 0.45 & 0.48 & 0.68 \\
& Minimum & 2 & 2 & 1 \\
& Maximum & 5 & 3 & 5 \\
\hline
\end{tabular}

\subsubsection{Machinery Industry}

In-depth data analysis in machinery industry companies revealed that there are major differences in relation to their origins. Nearly $90 \%$ of Polish companies reported the $1^{\text {st }}$ or $2^{\text {nd }}$ level of maturity in project management in the knowledge management area and, in almost $52 \%$ of cases, it was at the 'initial' level. In sharp contrast, $99 \%$ of foreign companies from that branch reached the $2^{\text {nd }}$ or $3^{\text {rd }}$ level of maturity and in nearly $84 \%$ of cases, it was at the second, 'standardized' level.

Regardless of their origin, a scant number of companies $(<2 \%)$ showed the fourth, or the fifth 'self-improvement' level of maturity. Furthermore, none of the foreign ones reported the lowest 'initial' level of maturity.

Figure 1. demonstrates the frequencies of reaching certain maturity levels by Polish and foreign companies of the machinery industry. 


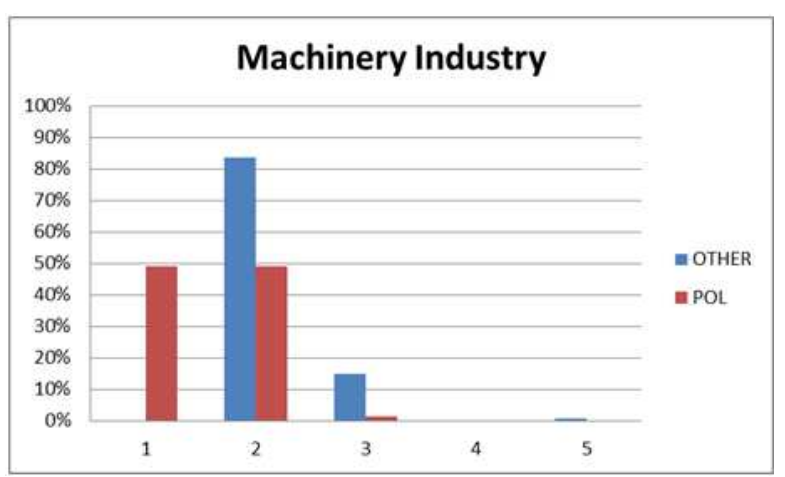

Figure 1. Frequencies of maturity levels for Polish (POL) and foreign (OTHER) companies in the machinery industry (IND)

\subsubsection{Construction Industry}

Nearly $99 \%$ of Polish construction companies reported the initial (1st) or standardized (2nd) level of maturity, while all foreign ones were at the standardized (2nd) or appliance (3rd) level. It is astonishing that none of them reported the first, lowest level of maturity, whilst $49 \%$ of Polish companies were at that level.

It is remarkable that in both groups of companies, there were no instances of reaching the 'system management' (4) or 'self-improvement' levels (5). Moreover, less than $2 \%$ of Polish companies reported the 'appliance' (3rd) level of maturity. This shows how immature the construction branch is in project knowledge management.

Figure 2. shows the frequencies of reaching different maturity levels by Polish and foreign companies active in the construction industry.

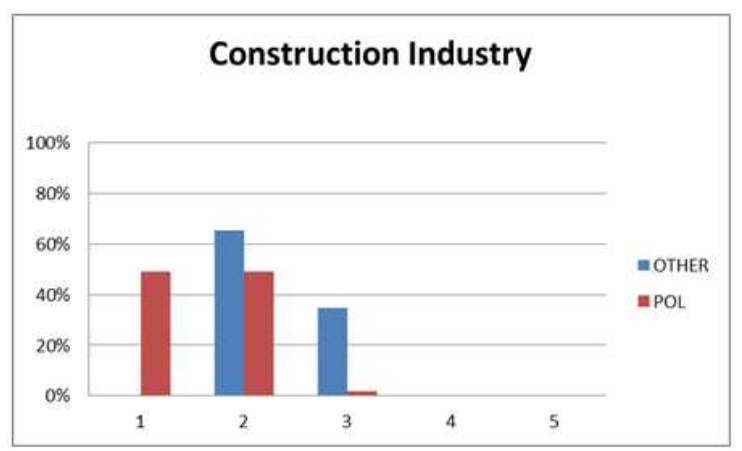

Figure 2. Frequencies of maturity levels for Polish (POL) and foreign (OTHER) companies in the construction industry (CONS)

\subsubsection{Information Technology Industry}

Polish and foreign information technology companies are the most alike in comparison to the construction and machinery ones. However, there are some differences as well. Although in both groups around $90 \%$ of companies reported the $2^{\text {nd }}$ or $3^{\text {rd }}$ level of maturity, there were $85 \%$ of Polish ones which reached level 2, while nearly half (49\%) of the foreign ones were at that level.

Furthermore, none of the Polish IT companies reached levels 4 or 5 , whilst the number of corresponding foreign ones was $2,5 \%$, a largely insignificant value; However, it could be the first sign of further investment in project knowledge management areas by companies. Although unlikely, the other two branches (only 5\% of Polish information technology companies) reported the initial level of maturity.

The graphical representation of the frequency of maturity levels of IT companies is shown in figure 3.

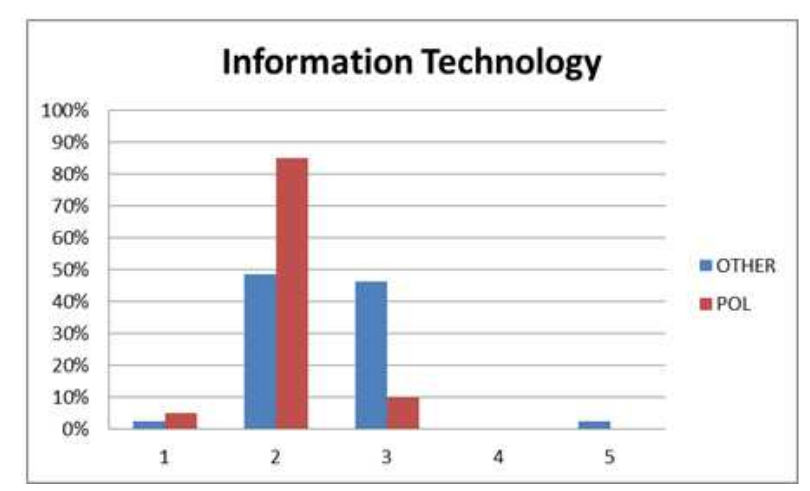

Figure 3. Frequencies of maturity levels for polish (POL) and foreign (OTHER) companies in information technology industry (IT)

\subsection{Comparison of Companies by Its Origin}

The data analysis revealed that the spread of data was low. Therefore, for a general discussion on the differences between the origin of the company and the maturity level in chosen areas, the mean value considerations are adequate.

Overall maturity distance, measured in mean values, between Polish and foreign companies in the knowledge management area is lower than 1. For the machinery industry and information technology, it is close to 0,5 , whilst for construction, 0,8 (see Figure 4.). Bearing in mind the results of mean values of maturity, such a small difference shows that companies, irrespective of their origin, do not devote the expected attention to managing projects' knowledge. Even if they did, they would likely not undertake effective activities to change this situation.

To increase the maturity level in the knowledge area, the companies should consider more intensively focusing on investments in activities and processes related to project knowledge management on different levels: individual, project and organizational [4]. On the individual level, knowledge is associated with performing separate activities and therefore needs to be applied to single task performance whilst on the project level, it's more about applying knowledge to the set of activities or phases of the project. The highest, 'organizational', level of knowledge application is dedicated to portfolio and program management issues and relevant knowledge application.

Small differences can also serve as support for the contention which states that the freshest ideas in management (and knowledge management is one of them) are spread out across the globe uniformly. This is a quite different situation to the one where the company needs to bridge the gap of knowledge which was created by geopolitical history. It thus takes time, for example, for post-communism block companies to adopt some standards which were developed by capitalism, often for decades. 
However, when it comes to the implementation of new ideas, the timeframe is comparable in different countries' history under the condition of free flow of knowledge and ideas.

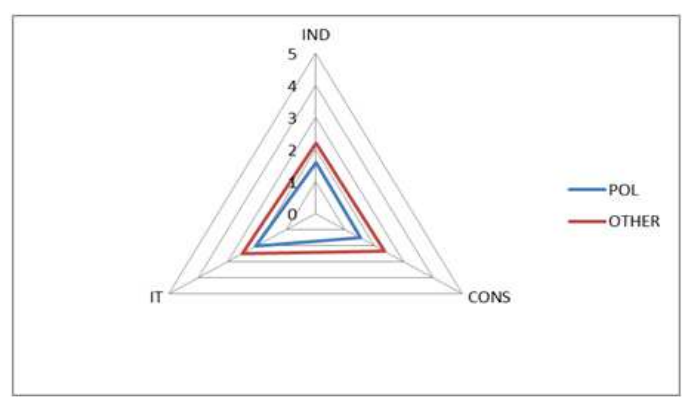

Figure 4. The comparison of mean values of project management maturity in the knowledge management area

\section{Conclusions}

Effectively managing knowledge in projects is the key factor in the company gaining a decisive advantage. This is of special importance in those organizations running a significant number of projects on a yearly basis. This creates a multi-project environment which could generate challenges. However, it should be perceived as an enormous source of information. The companies which are able to profit out of this situation will definitely gain a competitive advantage on the market as the fast and efficient application of knowledge to the projects can effectively reduce their duration, budget and enhance the quality of their outcomes.

If asked, the companies would confirm the importance of the knowledge management system. However, observable practice is largely distant from expectations [47-49]. Companies, in most cases, do not have any systematic approach to knowledge management. They fail to identify and capture the requisite knowledge. Such a situation is observed not only in the project management area, but in general management issues as well. From the company perspective, in theory, knowledge management is a must. However, in practice, they do not encourage the workers to share their knowledge. There is no incentives system which would enable people to gain some benefits if they transferred their invaluable knowledge to the data repository. Therefore, in fact, even if the company has a data repository, it is in most cases nearly empty or compiled with useless data.

The existence of a gap in knowledge management between theory and practice, noticed in the other management disciplines, was also confirmed by this study. Regardless of the specifics of the data sample (type of industry, country of origin), the general conclusion is that companies are on relatively low levels on the assessment scale. The vast majority reported the lowest 'initial' or the second 'standardized' levels of maturity. According to the assumed model, the 'initial' level means that the projects are executed in a rather chaotic way. Therefore, it is even hard to say that they manage the projects from the knowledge area perspective. However, there are some positive signs coming from the foreign companies. Those which reached the $3^{\text {rd }}$ (Appliance) level of maturity seem to understand how important it is to apply the knowledge management mechanisms in practice.

A highly practical way of enhancing project management maturity in the knowledge management area, in most cases, is through the establishment of a project management office (PMO) in the company's structure. This entity will ideally be responsible for facilitating knowledge transfers between different players in the project world. The PMO is designed to build and maintain the data repository and ensure that it is fed the proper data. Furthermore, the PMO should increase awareness of data sharing between workers and implement the incentives systems for individuals willing to share their knowledge with others or with the organization.

Like each study, this one also has its limitations. The sample size in each industry is limited, especially in the construction and information technology domains. However, the main goal was to investigate the machinery industry and it was achieved to a satisfactory level.

Another limitation is the number of investigated industries. Therefore, further studies in other branches are advised.

Being aware of its limitations, the study revealed that the most mature branch in knowledge management is information technology whilst the other two sectors, construction and machinery, represent somewhat similar maturity, with the latter one slightly lower.

Although the foreign companies in all branches reported overall higher levels of maturity than their Polish counterparts, the differences were not so high. This shows that the flow of information regarding knowledge management is transnational in nature. However, it also entails that the companies which decide to significantly invest in the project knowledge management area can gain a competitive advantage in their branch. The difficulty is that building an efficient project knowledge management system is a time consuming activity. That could be another obstacle which hampers the increase of project management maturity in that area. Nowadays, companies expect a fast return on investment and investing in knowledge management is not of that nature. Moreover, it is difficult to measure the results of such an investment over time as the project's outcomes depend on several internal and external factors. All of those factors are reflected in the results of this study.

The pioneers in investing in an increase of maturity level in project knowledge will benefit from that. Finally, foreign IT industry companies look like being the first among the group of investigated companies to acknowledge this.

\section{Acknowledgements}

This work was supported by the National Science Center grant. 


\section{References}

[1] Spalek S. Does Investment in Project Management Pay Off? Industrial Management \& Data Systems. 2014;114(5).

[2] Jugdev K, Thomas J. Project management maturity models: the silver bullets of competitive advantage? Project Management Journal. 2002;33(4):4-14.

[3] Davenport T. Saving IT's Soul: Human Centered Information Management. Harvard Business Review. 1994;72(2):119-31.

[4] Gasik S. A Model of Project Knowledge Management. Project Management Journal. 2011;42(3):23-44.

[5] Spalek S. The role of project management office in the multi-project environment. International Journal of Management and Enterprise Development. 2012;12(2):17288.

[6] Turner JR. The handbook of project-based management: McGraw-Hill London. 1999.

[7] Stabryla A. Zarządzanie projektami ekonomicznymi i organizacyjnymi. Warszawa: Wydawnictwo Naukowe PWN. 2006.

[8] Kerzner H. Project management: a systems approach to planning, scheduling, and controlling. 11 ed. Hoboken, NJ: John Wiley \& Sons. 2013.

[9] Trocki M, Wyrozebski P, Grucza B, Metelski W, Juchniewicz M, Buklaha E. Metodyki zarządzania projektami. Trocki M, editor. Warszawa: Bizarre. 2011; p. 365 .

[10] PMI. A Guide to the Project Management Body of Knowledge (PMBOK® Guide) - Fifth Edition: Project Management Institute (PMI). 2013.

[11] OGC. PRINCE2 Maturity Model (Version 1.0). London, UK: Office of Government Commerce. 2006.

[12] International Project Management Association. ICB - NCB IPMA competence baseline, version 3.0. Nijkerk: Author. 2006.

[13] Skrzypek E, Hofman M. Zarzadzanie procesami w przedsiebiorstwie. Wolters Kluwer Polska. 2010.

[14] Turner R, Ledwith A, Kelly J. Project management in small to medium-sized enterprises: Matching processes to the nature of the firm. International Journal of Project Management. 2010; 28(8):744-55.

[15] Nowosielski S. Dojrzałość procesowa a wyniki ekonomiczne organizacji. Prace Naukowe Uniwersytetu Ekonomicznego we Wrocławiu. 2012;(264):354-69.

[16] Wendler R. The maturity of maturity model research: A systematic mapping study. Information and Software Technology. 2012;54(12):1317-39.

[17] Hillson D. Assessing organizational project management capability. Journal of Facilities Management. 2003;2(3):298311.

[18] Ellis K, Berry DM. Quantifying the impact of requirements definition and management process maturity on project outcome in large business application development. Requirements Engineering. 2013;18(3):223-49.

[19] Rapaccini M, Saccani N, Pezzotta G, Burger T, Ganz W. Service development in product-service systems: a maturity model. Service Industries Journal. 2013;33(3-4):300-19.

[20] Williams JL. Mold Building and Project Management Maturity. Plastics Engineering. 2013;69(5):26-33.

[21] Almahmoud ES, Doloi HK, Panuwatwanich K. Linking project health to project performance indicators: Multiple case studies of construction projects in Saudi Arabia. International Journal of Project Management. 2012;30(3):296-307.

[22] de Oliveira AC, Kaminski PC. A reference model to determine the degree of maturity in the product development process of industrial SMEs. Technovation. 2012;32(12):67180.

[23] Gladden R. The Project Risk Maturity Model: Measuring and Improving Risk Management Capability. Project Management Journal. 2012;43(5):101-106.

[24] Pretorius S, Steyn H, Jordaan JC. Project Management Maturity And Project Management Success In The Engineering And Construction Industries In Southern Africa. South African Journal of Industrial Engineering. 2012;23(3):1-12.

[25] Spalek S. Reaching Maturity through Project-Based Learning. Knowledge and Learning: Global Empowerment; Proceedings of the Management, Knowledge and Learning International Conference 2012. 2012:519-23.

[26] Willis CJ, Rankin JH. Demonstrating a linkage between construction industry maturity and performance: a case study of Guyana and New Brunswick. Canadian Journal of Civil Engineering. 2012;39(5):565-78.

[27] Jia G, Chen Y, Xue X, Chen J, Cao J, Tang K. Program management organization maturity integrated model for mega construction programs in China. International Journal of Project Management. 2011;29(7):834-45.

[28] Juchniewicz M. Dojrzałość projektowa organizacji. Warszawa: Bizarre. 2009; p. 141.

[29] Wang HF. Capability maturity model for risk management in ERP/ERPII implementation project. $\mathrm{Wu} \mathrm{D}$, editor. Toronto: Universe Academic Press Toronto. 2008:143-147.

[30] Grant KP, Pennypacker JS. Project management maturity: An assessment of project management capabilities among and between selected industries. IEEE Transactions on Engineering Management. 2006;53(1):59-68.

[31] Wittek Z. Dojrzałość projektowa organizacji jako potencjał rozwojowy przedsiębiorstw. Prace Naukowe Uniwersytetu Ekonomicznego we Wrocławiu. 2011;(218):282-290.

[32] Twaites G, Collofello J, Zenzen F. The CMMI - More than just process. Tenth ISSAT International Conference on Reliability and Quality in Design, Proceedings. 2004:309-14.

[33] Khoshgoftar M, Osman O. Comparison of Maturity Models. Li WH, Zhou JH, editors. New York: IEEE. 2009:297-301.

[34] PMI. Organizational Project Management Maturity Model (OPM3 $\left.{ }^{R}\right)$, Knowledge Foundation - 2nd Edition. Newtown Square, PA, USA: Project Management Institute. 2008; p. 204. 
[35] Basu R. Managing quality in projects: An empirical study International Journal of Project Management. 2014;32(1):178-87.

[36] Haug A. Improving the design phase through interorganisational product knowledge models. International Journal of Production Research. 2013;51(2):626-39.

[37] Liebowitz J, Ayyavoo N, Nguyen H. Cross-generational knowledge flows in edge organizations. Industrial Management \& Data Systems. 2007;107(8):1123-53.

[38] Jemielniak D, Kozminski AK. Zarza $\square$ dzanie wiedza $\square$. Warszawa: Wolters Kluwer Polska. 2012; p. 496.

[39] Palacios-Marques D, Cortes-Grao R, Carral CL. Outstanding knowledge competences and web 2.0 practices for developing successful e-learning project management. International Journal of Project Management. 2013;31(1):14-21.

[40] Piraquive FND, Garcia VHM, Aguilar L. Technological Tools Virtual Collaborative to Support Knowledge Management in Project Management. 7th International Conference on Knowledge Management in Organizations: Service and Cloud Computing. 2013;172:163-74.

[41] Spalek S. Improving Industrial Engineering Performance through a Successful Project Management Office. Inzinerine Ekonomika-Engineering Economics. 2013;24(2):88-98.

[42] Pasian BL. Project management maturity: a critical analysis of existing and emergent contributing factors. Sydney: Faculty of Design, Architecture and Building, University of Technology. 2011; p. 266.

[43] Kimura F, Obashi A. International Production Networks in Machinery, Industries: Structure and Its Evolution. Faculty of Economics, Keio University, Japan. 2010.

[44] GTI. The Machinery \& Equipment Industry in Germany. Industry Overview. 2013.

[45] Velden Jvd. Market Surveillance Package and Product Safety -Preserving a Competitive Machinery Industry in Europe. 2013.

[46] Spalek S. Dojrzałość przedsiębiorstwa w zarządzaniu projektami. Gliwice: Wydawnictwo Politechniki Śląskiej. 2013.

[47] Liebowitz J. Cultural resistance to KM persists. Knowledge Management World [Internet]. November/December 2012; 21(10).

[48] Spalek S. Dzielenie się wiedzą projektową w polskich przedsiębiorstwach. Zarys problematyki. Zarządzanie i Finanse, Journal of Management and Finance. 2013;11(1 Part 2):305-15

[49] Wyrozebski P. Praktyki zarządzania wiedzą projektową w polskich organizacjach - wyniki badań. E-mentor, Szkoła Główna Handlowa. 2011;42(5):64-75. 